\title{
Cameroon: State Policy as Grounds for Indigenous Rebellion. The Bakweri Land Problem, 1946-2014
}

\author{
Venantius Kum NGWOH
}

\begin{abstract}
The history of Africa in recent years has been marked by instability in the form of separatist movements, agitations for political rights and freedoms as well as open resistance against government action. This study about conflict over natural resources explores the leeway as well as the mechanisms that enhanced the alleged loss of land rights by Bakweri people in Fako Division of Cameroon and evaluates efforts they exerted to retrieve these appropriated lands. Cameroonian post-colonial state policy between 1963 and 1974 invalidated the provisions of a 1958 Land and Native Rights Ordinance that had re-established customary rights over colonial entitlements to land thereby transforming homegrown people from owners to holders of their ancestral lands. This policy was exactly calculated to extort the inalienable communal property of the various peoples whose privileges to land were based upon immemorial usage and who were attached to their lands in life and limb. After about a century of persistent land hunger, they formed a Bakweri Lands Claim Committee (BLCC) to wrest their ancestral lands from alien occupants. Although the confrontation raged for about 150 years, the divide-and-rule policies of successive governments invalidated their efforts. According to research findings, the exacerbation of this imbroglio was another ploy by a French-speaking dominated apparatchik to totally dismantle and disrupt the nascent economy of the English-speaking part the country. Through their actions, government officials authenticated the fact that Cameroon law did not protect indig-

Venantius Kum NGWOH, Ph.D. Department of History, Faculty of Arts University of Buea

Email: ngwoh.venantius@ubuea.cm

Conflict Studies Quarterly

Issue 27, April 2019, pp. 39-58

DOI:10.24193/csq.27.3

Published First Online: 01/04/2019 enous minority rights and openly demonstrated that Bakweri land rights could only be restored if Decree No. 74-1 of July 6, 1974 that established rules governing land tenure in Cameroon was amended. Whereas the Bakweri indigenes have struggled to restitute their land rights, the regime consistently exerted its authority by invoking the law that declares inter alia, "... the state shall be the guardian of all lands". But strangely enough, BLCC members have hailed this same law as a confirmation of their rights of private ownership and in 1999, their chiefs stated em-
\end{abstract}


phatically that "this cannot possibly apply to CDC occupied lands [which] were known even to the German colonial administration and would have featured in the official German land registers.... Thus, while the Bakweri claimed private property rights, the state remained unyielding that the assertion was a farce and that is why its authority has remained primordial in a land surrender process that it initiated in 2003 and halted in 2014.

Keywords: Bakweri, Germano-Duala Treaty, grundbuck, "Kamerun idea", land surrender.

\section{Introduction}

On July 4, 2007, some Bakweri indigenes from 19 villages in Fako Division descended on 15 hectares of a Cameroon Development Corporation (CDC) ${ }^{1}$ plantation at Liongo to deracinate banana plants. Their action was symptomatic of an age-old dispute pitting the Bakweri Lands Claim Committee (BLCC) ${ }^{2}$ against the Cameroon government since 1946, while "the health hazards of CDC's economic activities on their children, together with its expansionist and expropriationist tendency towards their ancestral lands" provoked their immediate hostility. ${ }^{3}$ This long lying brawl was over the ownership, control and use of over 250000 hectares of land from which they were "uprooted from the homes of their forebears, settled willy-nilly on strange soil, deprived of their old-time hunting grounds and fishing rights..." between 1858 and 1905 (Dibussi, 2006).

Whereas the Bakweri indigenes had been struggling for decades to have their land rights restituted, the regime consistently exerted its authority by invoking the land law of 1974 that declares inter alia, "... the state shall be the guardian of all lands". But strangely enough, BLCC members continued hailing this same law as a confirmation of their rights of private ownership and stating emphatically that "this cannot possibly apply to CDC occupied lands [which] were known even to the German colonial administration, and would have featured in the official German land registers..."4 (Fako Chiefs, 1999). Thus, whilst the Bakweri continued to claim private property rights, the state remained adamant and considered the assertion as a farce.

1 The CDC came into existence on January 1, 1947 in accordance with Ordinance No. 39 of 1946. It took over and managed the German plantations leased to it by the Nigerian government on Certificates of Occupancy for 60 years.

2 The BLCC was established on June 18, 1946 to fight for the restoration of indigenous land rights and is looked up to as the accredited mouthpiece of the Bakweri.

3 The banana suckers were uprooted from a plantation sharing boundaries with a government primary school in Liongo whose pupils were usually affected by insecticides when CDC bananas were sprayed.

4 This opinion was expressed by over 300 Bakweri chiefs, notables and elites in 1999 in reaction to the announced privatization of the CDC. 
The main thrust of this paper is to provide an academically tailored sequential version of the Bakweri land case. This will be done firstly by exploring the leeway as well as the mechanisms that enhanced their alleged loss of land rights; secondly, by evaluating the efforts that the BLCC made to retrieve these appropriated lands and then thirdly, assessing the effectiveness of the famous CDC land surrender palaver.

\section{The alleged loss of land rights by the bakweri, 1858-1974: motivations and techniques}

The Bakweri are found in Fako Division that was an integral part of the former British Southern Cameroons. They are settled on the eastern and southeastern slopes of the Cameroon mountain, where the Germans appropriated vast expanses of fertile lands spreading to the Victoria (Limbe), Mutengene, Tiko, Muyuka, Ekona and Buea areas (Ngoh, 1996). Their socio-economic activity is based mainly on hunting, fishing and subsistent farming whereby maize, cassava, yams, cocoyams, plantains, groundnuts andegussiare grown. There is industrial fishing around Bimbia, Bibundi and the southern parts of Limbe (Mbuagbo \& Lambi, 2003). The plantations set up by German enterprises in this division are run by the $\mathrm{CDC}$ as well as privately owned enterprises like the Cameroon Tea Estate (CTE). ${ }^{5}$ These occupy the greatest part of the fertile plains thus creating intermittent outbursts of disagreements over land rights.

The rich volcanic soils on the slopes and foot of the mountain, formed from the decomposed lava released during eruptions, were attractive to German citizens for large tropical plantations. The cold climate with local variations in rainfall and temperature was suitable for European settlement and growth of a wide range of crops. In this way, Germany could cultivate better quality crops in her own colony instead of buying from foreign markets, which was expensive and uneconomical. No wonder, the German colonial authorities were compelled to devise ways and means of securing the land for their use.

The world over, human communities are guided by land tenure which is a mechanism or set of rules that govern the acquisition, ownership, control, use and cession of land by individuals and communities from generation to generation. According to Cheabi (1997), it is "the system that assigned [as well as] protected the homestead" and is of great value in that it indemnifies family or individual access to land on which they can build and from which they can acquire food. The necessity of such a scheme was spawned by the fact that "land was considered sacred and the king did fertility rites

5 CTE is a shell company comprising CDC tea estates in Tole, Gbiyuku and Sachsenhof (on Bakweri land) that were sold to Alhadji Baba Amadou Danpullo (leader of Brobon Finex, a South African Company) in 2002 for 1, 5 billion F CFA. This amalgamation was done by John Niba Ngu, former CDC General Manager and Minister of Agriculture who masterminded the privatization in 1999. 
intermittently to protect it" (Ngwoh, 2016). Thus the inability of the Bakweri to protect the tenets of their land tenure inescapably led to its demise and their loss of land rights. Worse of all, the new colonial economic mentality in which "the man with the purse" played a dominant role in Europeanized society influenced the coastal people to start selling their land, thereby contributing to the waning or out-and-out alteration of the land tenure system ${ }^{7}$ (Mbuagbo \& Lambi, 2003).

When the Germans realized that it was only through the establishment of their own plantations that they could have a regular supply of raw materials, the need to acquire land from the indigenes by any means possible was heightened. Over and above all this, they were not sure to have a regular supply of agricultural raw materials from the subsistent farming practiced by the indigenous people because local hostility and the absence of roads disrupted the supply of tropical products from the interior to the coast. Being latecomers in the scramble for Africa, the Germans were eager to exploit Cameroon and make as much profit within a short while as possible. ${ }^{8}$

The German land acquisition scheme was indeed elaborate. An official letter dated May 6, 1884 from Adolf Woermann instructed German colonial officers on the ground to, by all means, acquire fertile land from the indigenes (Ambe, 1999). This justifies the wholesome expropriation of large land areas, the creation of the Colonial Economic Committee (CEC) ${ }^{9}$ in 1898 and the opening of plantations in locations like Idenau, Debuncha, Moliwe, Meanja, Ekona, Mukonje and Tiko for the cultivation of palms, rubber, tobacco, banana and tea (Ngoh, 1996).

The establishment of large-scale plantations necessitated massive mobilization of labor, which the indigenous Bakweri population refused to supply thereby opening

6 In African tradition, land has an economic, cultural plus a religious value and so it is anathema to dispose of it.

7 According to the Food and Agricultural Organization (FAO), extensive surveys through Africa in the early 1960s showed that the system whereby free land and ownership are granted to indigenous persons is defective, because the surest way to deprive an African of his land is to give him ownership. Since the average citizen in the village owns practically nothing of economic value, giving him ownership means that the land has become his private property over which he has the right to sell. He sees in the sale of his plot the possibility to have some money, much more than he can get from his work, thinking that if he can't find other free land on the spot, it will be available in some other place.

8 By 1883, Germany was not interested in the acquisition of overseas territories because after unifying in 1871, she needed to industrialize and pursue internal reorganization in order to tilt Europe's balance of power to her favor. But this policy changed after the Berlin Colonial Conference (18841885) because Otto Von Bismarck desired "a place in the sun" for Germany.

9 The German Colonial Society, the German Ministry of the Interior as well as contributions from the German public, funded the CEC. Its principal function was to designate sub-committees with specific functions such as the Central Botanical Bureau that was chiefly concerned with scientific research. 
the floodgates for migrant workers from other areas of Cameroon to the coastal plantations.$^{10}$ Accordingly, this region witnessed a dramatic increase in the population of non-indigenes, who soon outnumbered their hosts. Due to the fertile nature of the soil, these immigrant populations, mostly from the grasslands regions of Cameroon, preferred to establish permanently exploiting the lands, thereby increasing the pressure on non-plantation lands. Coming from areas of poor soils, they were generally more hardworking, a quality that brought much wealth to them, sometimes to the envy of the indigenes who felt threatened by the strangers' economic power ${ }^{11}$ (Mbuagbo \& Lambi, 2003). This situation quite often generated petty jealousies, which strained relationships between original inhabitants and settlers over the question of land ownership.

The expulsion of the Baptist Missionaries from Fernando Po triggered their need for land where they could settle, organize themselves for evangelization, relocate free or abandoned slaves and promote legitimate trade ${ }^{12}$. This explains why Alfred Saker arrived in Victoria on June 9, 1858 and "contacted King William of Bimbia who claimed to have had unlimited powers over the land, arranging for its purchase" (Ngoh, 1996). The signing of a treaty by Alfred Saker and King Bille (William of Bimbia) on August 23,1858 sanctioning the purchase of 50 square miles of land for $£ 2000$ to set up the Victoria Settlement marked the beginning of the loss of land rights by the Bakweri (Ngoh, 1996). The exchange of cash for land implied loss of control because it had passed from communal to private ownership. Fences as well as other demarcationswere erected and the words 'private property! Keep off!' were affixed to them (Cheabi, 1997).

The land appropriation ploy of German colonial and indigenous authorities constituted treachery, outright manipulation, forgery, corruption and brutality. This enabled them to secure enormous parcels of fertile land free of charge and in rare cases, at the token sum of five Marks per hectare. The most prominent land acquisition scheme of the imperial authorities was the hobbyhorse of Von Puttkamer, designed to resettle all Fako people in reservation enclaves (Kale, 1967). This was under the auspices of the Crown Lands Act of July 15, 1896, which officially converted all so-called "unoccupied land" throughout Cameroon into the property of the German overseas dominion (Ambe, 1999). Given that the population density of Fako during the German colonial era was

10 This objection was a reaction of the indigenes to their loss of land rights and their restriction to unproductive areas.

11 Most of these migrants were from the grasslands regions (North West and West Provinces) of Cameroon where volcanic soils are absent. Through the fruit of their labor, they were able to make substantial economic investments better than the indigenes.

12 The arrival to Fernando Po of Spanish Catholics in 1856 marked a turning point in the personal liberty, property and religion of Baptist missionaries. They were compelled to leave Fernando Po in 1858 when the Jesuits arrived and proclaimed Catholicism the sole religion in the island. 
something below one person per square kilometer, almost all land in the neighborhood became crown land.

Two land sale agreements in 1887 between Buea chiefs and German officials point to the fact that land was sold to the Woermann and Jantzen und Thormalen firms. In a letter written at Mapanja on February 18, 1887 by George Valdau to Governor Von Soden, the purchase was reported thus: "Yesterday I succeeded in buying whole Buea for you...I could not get all the kings [and] chiefs together at one time because the upper and lower Buea are enemies and must, therefore, make two contracts... The Buea people will come to Mapanja and receive the payments.... On March 4, 1887, an accord was signed certifying that 10 Buea chiefs had "received from the imperial Governor Herr Von Soden the contracted purchase price for the whole land in Buea...The [...] people confer upon the imperial governor, or his successor in law, an unrestricted prior right of purchase to the land..." (Tande, 1999, p. 45). ${ }^{13}$

The so-called contracts of sale were contentious on many counts: (a) the agreements were vague since neither the measure of land sold nor their purchase price was mentioned; (b) African chiefs and European governments had absolutely opposed philosophies of what land sales entailed and (c) land that was sold in parts of Buea should not have been extrapolated to the entire Fako Division. In the territorial map drawn by Dr. Preuss in 1897, the area in question covered a mere 212 hectares while the entire vicinity whose competition for control later became a long-standing boon of contention covers 250000 hectares (Dibussi, 2006).

By 1892, Bakweri land had largely become a German territory and so they set out surveying and piecing it out. Since the indigenes did not understand what these demarcations were all about, they remained unconcerned. But when atrocious methods compelled them to get rid of their houses, there was opposition (Kale, 1967). Thus, through the above devices and machinations, substantial portions of Bakweri land were expropriated and the people alienated from their lands. By 1914, German companies and individuals involved in large scale plantation agriculture owned, controlled and used the most fertile parts of Bakweri ancestral lands. Having been thus deprived, the people tried eking a living by farming on rocky mountain slopes where no economic crop could thrive. Some parts of Buea were proclaimed "crown lands" where the indigenes were prohibited from farming and lumped up in reserves that were relatively less productive. Since rocky barren upland slopes, swamps and bogs occupied such localities, the issue of land then became a matter of life and death especially as the areas mentioned in Table 1 did not include plots in Buea alienated to Messrs Holtforth, Justo Weiler, Baptist and Basel missions.

13 This file was uncovered by Jovita Nsoh in the Colonial Section of the German National Library in Berlin in 1999 from which he collected data to use as his contribution to the Internet Debates on the Bakweri land problem. 
Although the BLCC adduced that German claims over their land were not authentic "as was the case with our brothers, the Dualas, who signed a treaty with the Germans in 1884 giving them their right of legislation over their lands, ${ }^{\prime 14}$ it must be considered that Buea was a casualty of German subjugation. The loss of land rights in the region was partly an outcome of the war they fought with the Germans from 1891 to 1894 leading to the assassination of General Von Gravenreuth on December 5, 1891, by Mondinde mo Ekeke. The subsequent death of Kuva Likenye, leader of the Bakweri and the surrender of his successor, Endeley Likenye to the German authorities in Douala in 1895, ended the war. This conclusion was endorsed by an armistice between the belligerents in which Endeley Likenye, Nyaneli and Ekeke Evakise represented the vanquished (Ngoh, 1996).

The terms of the armistice were catastrophic as they aggravated the confiscation of their landed property. Nevertheless, this defeat did not justify the whole scale expropriation and subsequent alienation of large expanses of their land. The Germans had captured only Buea, not other parts of Fako, making this acquisition process illegal. In any case, their hegemony over this land was short-lived following Germany's defeat in World War I resulting in the loss of all her colonies including Cameroon that became a League of Nations mandate. ${ }^{15}$

In 1920, the British parliament made proclamation No. 25 ceding German-owned estates to the Nigerian government through which Britain administered the League of Nations mandated territory of the Cameroons (Ambe, 1999). These ex-enemy possessions, administered by the Custodian of Enemy Property, ${ }^{16}$ were put under auction in London in October 1922. The need to dispose of these estates was urgent because the British colonial government perceived their maintenance as an economic burden. Since the October auction turned out to be a fiasco, another one was organized from November 24-25, 1924 and a London estate agent who actually acted on behalf of the former German owners bought all the plantations for $£ 224$ 670. In addition to land, the sales included railway system, rolling stock, wharves, dwellings and factories (Ngoh, 1996).

But this private ownership of the ex-German plantations did not last long because, after World War II, the Custodian of Enemy Property re-expropriated them. In 1946, the Nigerian legislature passed Ordinance No. 38 providing for the acquisition of lands formerly owned by Germany in the British mandate of the Cameroons. The Governor of Nigeria bought these lands for $£ 850000$ and leased them out to the CDC that was

14 According to the Germano-Duala Treaty of July 12, 1884, some Douala chiefs ceded their rights of sovereignty, legislation and administration over a geographically determined territory named Cameroon to the German government through private firms.

15 Article 119 of the Treaty of Versailles obliged Germany to relinquish control over all her colonies. Cameroon became a mandated territory under Britain and France.

16 The CEC was an economic institution set up by Britain to administer confiscated German property. 
established the same year to develop its plantations, provide social welfare facilities to its employees, inter alia (Bederman \& Delancy, 1980).

While the BLCC was expecting to take over control of these lands when the lease expired, the country's indigenous authorities did a lot more between 1963 and 1974 to obliterate its claims o land. Decree No. 63-2 gave the signal on June 9, 1963 by invalidating the provisions of the 1958 Land and Native Rights Ordinance that had re-established customary rights over colonial entitlements to land (NAB File No. 23 829, 1943). To this effect, all claims to land not supported by prescribed or current instruments were declared ultra vires. More substantive land-related vocabulary such as "owners" and "landlords" previously used in referring to the rights over ancestral lands held by members of the homegrown populations were rendered redundant in favor of inconsequential ones like "holders" and "occupants" (Ngwoh, 2016). Thus the 1963 law was the bedrock that transformed the status of the Bakweri from owners to holders of their ancestral lands and laid the foundation for their rebellion against state policy.

To follow this dispossession exercise to its logical end, lands that were not actually occupied i.e. les terres vacantes ou sans maitre throughout the country were classified as le patrimoine collectif national. To make matters worse, the registration or formalization of collective customary rights on land was made obligatory by repealing a 1932 colonial law, which recognized les droits fonciers sans titre ecrite (Ambe, 1999) ${ }^{17}$. This had been exactly calculated to extort the inalienable communal property of the various peoples whose privileges to it were based upon immemorial usage.

Having thus set the foundation in the manner illustrated above, Decree No. 73-3 of July 9, 1973 allowed President Amadou Ahidjo "to establish rules governing land tenure in the country". Equipped with such powers, he ratified Decree No. 74-1 of July 14, 1974 that became the country's landmark land law. The interpretation of its major provisions is the principal source of the contested hegemony over land in Fako Division between the government and some Bakweri indigenes under the patronage of the BLCC.

\section{The Struggle for the Restoration of Bakweri Ancestral Lands}

BLCC's greatest worry was that government continued to exert its authority on the land saga by invoking the land law of 1974 that classifies land into four categories including national land, private state land, private corporate and the land of individuals (Bakweri People, 1999). As custodian of all land, the state claims to have powers to intervene in land matters to ensure its rational use for the promotion of the economic policies

17 Members of most indigenous communities in Cameroon have been ignorant of the fact that only authentic land certificates can guarantee any claims to their ownership of ancestral lands. This explains why intrastate conflicts over land are perennial and why indigenes look at government's role in allocating land to settlers as infringements on their natural rights. 
of the nation. This means that government can invoke whatever reason to justify the expropriation and alienation of any piece of ancestral lands.

But the committee disproved the argument of state ownership over its lands because antecedent rights survived the change of sovereignty from the British crown to the state of Cameroon. In 1946, the Nigerian legislature re-appropriated these lands by buying them for the governor to hold in trust for the people. This repurchased asset was recognized as indigenous private property by a special resolution adopted at the Sixth Meeting of the United Nations Trusteeship Council in March 1950 (Kofele-Kale, 2007). In this wise, Bakweri indigenes saw it a bounden duty to fight for the return of their lands for "if fighting for our lands is wrong, then what is right?".

Apart from regular meetings held, they had, at individual and collective levels, addressed petitions, memoranda and complaints expressing their bitterness and laying claims to their lands. Their targets were the German and British colonial governments, UN Trusteeship Council, the Cameroon government and African Court at Banjul (Dibussi, 2006). They had every reason ${ }^{18}$ to make regular objections to the Reichstag against Von Puttkamer and the chief judge Von Branchitsch a propos the forceful acquisition of lands for plantations in which they were financially interested. These complaints caused the German parliament to start an inquiry in 1907. When Karl Ebermaier came to office in 1912 as German imperial governor, he made a seven days tour of Bakweri villages after which he became fully convinced that amends were needed. But the land crisis remained unsettled when World War I broke out in 1914 and prevented Van da Laan from effecting an assignment to re-survey the land in order to determine the people's needs and grant them (Kale, 1967).

The first attempt by the BLCC in its struggle for the restoration of land rights was made on August 7, 1946 in a petition to the chief secretary of the Eastern Region in Enugu demanding a return of the plantation lands together with financial compensation commensurate to the years of exploitation. In response, he "promised sending out a surveyor to see whether any increase of land was necessary and whether the indigenous population had augmented". Far from pacifying the people, this reply incensed them "as they were not asking for an increase but for a return of the whole land" (National Archives Buea, 1946).

18 Robert Kuczynski observed that this massive expropriation scheme muffled the political sovereignty of the Bakweri, as it had no consideration for their economic empowerment and liberation. Their relegation to reserves to a large extent made them lose interest in life, as was demonstrated by the dilapidated state of their houses and their neglect of most sanitary measures in spite of years of culture contact with Europeans. The left over areas were unfavorable for cultivation thus breeding malnutrition and exposing the women, who by routine were the planters of their locally consumed foodstuff, to profound injuries. What is more, they were victims of infant mortality and early breakdown in health. 
The petition that actually opened the Bakweri land case was addressed to the British Secretary of State for Colonies on June 24, $1946^{19}$. In it, they clearly stated the particulars of their case and laid four claims, namely: that all "crown lands" should become indigenous lands controlled by them; all alienated land under British mandate belonging to the Bakweri should be returned; the Bakweri should be remunerated for the many years of utilization of their land and that all mission lands be given back except plots occupied by schools, churches and residents of missionaries (National Archives Buea, 1946).

Both the United Kingdom (UK) government and Trusteeship Council responded positively to this request thus playing positive roles in facilitating the struggle. Thisis seen in the fact that BLCC gained some concessions from the British government when she requested the UN to grant the committee a hearing in 1947. Article 8 of the trusteeship agreements on Cameroon unequivocally stated that in framing laws relating to the transfer of land and natural resources, the administering authority should take into consideration indigenous laws as well as customs; respect the rights and safeguard the interests of all generations of the indigenous population. ${ }^{20}$ Although BLCC lost its best chance to present its case in New York, ${ }^{21}$ the UK government still forwarded certain observations to the UN Secretary-General on June 9, 1948 in which it was pointed out that:

... all lands had been declared [indigenous] lands and had been placed under the control of the governor of Nigeria to be administered for the use and common benefit of the indigenes; that the Nigerian government had repurchased 14851 acres of plantation land for the benefit of the indigenes... (BLCC, 1948).

Although the committee never had another chance to present its case directly to the UN, it met with various delegations from the Trusteeship Council visiting the Southern Cameroons. In the same year that these land rights were restored to the indigenes, Ordinance No. 39 created the CDC to which

... the lands were subsequently leased ...for a period of 60 years on terms which expressly provided for reversionary rights... [The] title to these lands never passed to the CDC... and the administering authority as well as successor independent Cameroon government was acting only as custodian, holding the land in trust for present and future generations of Bakweri people... (Bakweri People, 1994).

19 David Endeley, Honorary Secretary of the BLCC, wrote both the first and second petitions. Arthur Creech Jones, British Colonial Secretary, received the second, co-signed by 25 prominent Bakweri, one year later.

20 The UN General Assembly approved these trusteeship agreements on Cameroon on December 13, 1946 and November 1, 1947.

21 The BLCC was unable to raise the sum of $£ 400.00$ to finance the trip of Dr. E.M.L. Endeley who was chosen as the representative at the UN in New York. 
After the reunification of the British and French Cameroons, the land problem was relegated to the background as Cameroonian political leaders turned their backs on "regional and parochial issues" in their pursuit of Pan Cameroonian issues. The case was further obliterated under the Amadou Ahidjo regime due partly to his over centralized system of government and partly because of his dictatorial tendencies. Thus the BLCC disappeared from the scene waiting for the appropriate moment to resurface even though the land issue refused to go away in the minds of its members.

This moment came in 1994 when President Paul Biya announced the privatization of the $\mathrm{CDC}^{22}$. The announcement provoked a wave of anger that swept across the entire division and caused its indigenes to revive the moribund BLCC under whose patronage Bakweri political, traditional and other leaders rallied to adopt a common position. The immediate reaction was that about 150 representatives of the Bakweri met in Buea on July 23, 1994 to discuss the implications of the decree. During the meeting, it was resolved that "the land and natural resources being exploited by the CDC belong to the indigenes of Fako and cannot therefore be alienated and/or transferred to nonindigenes" ${ }^{23}$ (Bakweri People, 1994).

This did not make any visible impact on the government. Accordingly, government ministers made numerous visits to Fako in order to convince the public that privatization was in their best interest. Even though BLCC members were not against the idea of privatization or sale per se, their quarrel was that CDC should not have been involved because "by all objective indicators, [the corporation] is efficiently managed". According to them, a sale will result in its plantation and lands being taken away by private interests [and so] the problem here is that CDC does not own the lands and cannot therefore transfer what it does not have (Bakweri People, 1994).

From every indication, the corporation was left with the status of a tenant whose duty was to develop the plantations and set aside sums of money annually in its operating accounts as ground rents paid to the public treasury (Kofele-Kale, 1994). These tours however, provoked the BLCC to come up with another memorandum in 1999 reiterating its earlier demands for the recognition of indigenous rights on CDC land, payment of land rents owed to the Bakweri Land Trust Fund and the direct involvement of the Bakweri in privatization talks.

22 The announcement to privatize the CDC was made on Thursday July 15, 1994 in Presidential Decree No. 94/125.

23 The meeting was co-chaired by Chief S.M.L. Endeley and Chief F. Bille Manga Williams. An ad hoc committee comprising Dr. S.N. Lyonga (Chairman), Prof. Ndiva Kofele-Kale (Secretary), Mr G.B. Mbua Mosoke, Mr Mokake Elali and Chief Mbella Sone Dipoke was set up to pursue the matter of privatization or sale of the CDC. 
Bakweri elite in the Diaspora supported the BLCC and asked "all men and women of good will to join in the struggle to protect the interest of ordinary Cameroonians who live in abject poverty and deprivation while their unaccountable leaders and their multinational partners exploit their heritage before their very eyes" 24 . The pressure exerted by the elite was regarded with hostility and this is evidenced by the fact that Fako Senior Divisional Officer (SD0), Jean Robert Mengue Meka, banned a planned BLCC meeting in Buea in March 2000. In a letter dated June 6, 2000, he instructed the BLCC leadership to put an end with immediate effect, to all activities of this illegal committee. Abogo Nkono, ${ }^{25}$ who denigrated the BLCC and declared that it had no locus standi to speak for the people, supported this stance (Monono, 2006).

The government ban on the BLCC made its leadership to drag the State of Cameroon to the African Commission on Human and Peoples' Rights (ACHPR) or Banjul Court ${ }^{26}$ in September 2002 on five counts, namely that lands occupied by the CDC are private property belonging to the Bakweri, the rightful owners of the land are not fully involved in the CDC privatization negotiations announced eight years earlier by the President of the Republic, ground rents owed the Bakweri people dating back to 1947 have not been paid to a Bakweri Land Trust Fund for the benefit of the dispossessed indigenes as demanded three years earlier, the Bakweri acting jointly and severally lack a specific percentage of shares in each of the privatized companies and BLCC has no representation in the current and all future policy and management boards, as was the case in colonial times (ACHPR, 2002).

During its $33^{\text {rd }}$ session in May 2003, the Commission requested the Cameroon government to suspend the alleged detrimental alienation of the disputed CDC lands in the Fako Division pending a decision on the matter before the African Commission. At its $36^{\text {th }}$ Ordinary Session, and in ruling No ACHPR/LPROT/COMM 206/CAM/NGL of February 3, 2006, the case was declared inadmissible for non-exhaustion of domestic remedies as required under Article 56(5) of the Banjul Charter. In addition, the commission offered to avail its good office to the contending parties to enable them resolve the

24 See also Letter from the Bakweri around the World to President Paul Biya of Cameroon dated October 1, 1999 with more than 140 signatories among whom were the UN Secretary General, President of the World Bank and Peter Mafany Musonge who was currently the Prime Minister of Cameroon.

25 Abogo Nkono, who was Cameroon Minister of Lands and State Property from November 8, 2004 to September 7, 2007, made this declaration in an interview granted to CRTV's Cameroon Calling Programme on Sunday September 16, 2006.

26 This was in accordance with Articles 55, 56 and 58 of the African Charter on Human and Peoples' Rights. This charter came into force on June 27, 1981, following the OAU Doc. CABILEG/67/3IRev.5, and it was adopted by the Organization of African Unity on June 27, 1981 and entered into force October 21, 1986. 
matter amicably and also referred the recommendation to the Assembly of the Heads of State and Government of the African Union for approval (ACHPR, 2006) ${ }^{27}$. When the Union gave its accord, the way was now open for both parties to enter into negotiations under the auspices of the Commission with a view to arriving at an amicable settlement in this long-standing land problem (Kofele-Kale, 2007). But, surprisingly, the Cameroon government went ahead to surrender portions of land to the indigenes, perhaps because the commission had no laid down law to supervise the implementation of its recommendations.

\section{The CDCL and Surrender Imbroglio}

From 2003 to 2014, the government of Cameroon, through the intermediary of some state agents at the regional and divisional levels of ministerial departments like Territorial Administration, State Property, Surveys and Land Tenure, working in tandem with CDC officials restituted some parcels of plantation land to Bakweri villages that expressed the need. This exercise whose initial intention was to appease the people instead boomeranged and created a slew of malpractices like excessive grabbing of communal land by non-indigenous senior administrators; indiscriminate sale of ancestral land by some insatiable Fako chiefs and elites leading to the transfer of native lands to more than $90 \%$ of non-natives; the creation of fake new layouts by dishonest administrators with the intention of acquiring and eventually selling Fako communal land; the sharing of land sale booty by an oligarchy and the emergence of a non-indigenous bourgeoisie class (Ngongi, 2013, 2014; Ngange, 2014).

For all the period that the Bakweri struggled to retrieve the totality of 250, 000 hectares of their ancestral lands, just a paltry 7,594 hectares was coughed out by the CDC. According to Eno and Fombe (2016), of the four sub-divisions that comprise Fako Division, Limbe had $45.6 \%$ because of her natural physical limitations imposed by the presence of the Atlantic Ocean, Buea received 37.9\% following her status of a University town which attracted the influx of students and workers, Tiko had $4.3 \%$ while Muyuka received $12.2 \%$. A closer look at the five principal land uses indicate that $58 \%$ was allocated for residence, $22 \%$ for schools, $16 \%$ for public spaces, $3 \%$ for religious centers and $1 \%$ for hospitals (Eno \& Fombe, 2016).

There was a well-defined procedure to be followed by the communities intending to benefit from the land surrender scheme. First of all, any village community with a recognized historical background or proof of its previous existence whose population ranged from at least 10 to 5,000 people, established a letter of motivation with evidence

27 But it is doubtful whether the Cameroon government has any intentions at heeding to the recommendations of the commission that has no laid down law to supervise the implementation of its recommendations although it has the authority to call any recalcitrant state to order. 
that the community needed more land for development. The traditional authority then wrote an application to the Senior Divisional Officer (SD0) Fako Division who set up a commission comprising the technical services of the relevant ministries, the CDC and the applicant. The commission's duty was to examine the request, identify a place depending on the availability of land in the area concerned, make recommendations and constitute a file comprising the applicant's request, minutes of its meeting and a survey map. The SDO then forwarded the file to the CDC for a decision by the Board of Directors. If the request was granted, the file was sent back to the SDO who transmitted it to the Ministry of State Property, Surveys and Land Tenure for the effective allocation of the land. In return, the beneficiary community paid the sum of three million FCFA as land cession fee as well as the purchase and implantation of survey pillars (Nana, 2014).

Population pressure, the quest for social facilities and the skyrocketing value of land and peoples' increasing awareness about land rights were the principal factors that engineered increasing demands for more land. This influx can be attributed to the geological, social and economic potentials of the area. By 1961, it comprised basically four council areas, about 125 village communities and less than 100, 000 inhabitants made up mainly by indigenous people who could have needed approximately 2, 000 hectares of land for their activities. But by the end of 2010, the population had more than quintupled while its rural nature had disappeared making the major townships like Buea and Limbe to be cosmopolitan and metropolitan. Thousands of people flocked into this area because of available employment opportunities at the CDC, an agro-industrial parastatal, being the country's second largest employer after the state. The country's lone refinery SONARA (Societe Natioanale de la Rafinnerie), which is located in Limbe also attracts people from all corners of the. The creation of the University of Buea in January 1993, followed by more than 30 other higher education institutions in subsequent years raised the student population in Buea alone from 1,500 in 1993 to more than 200,000 in 2010 (Neba, 2010).

Increasing demands for more land could further be explained by the fact that land is viewed as a political instrument, an economic asset and a spiritual tool. For political purposes, its acquisition, ownership, control and use have historically been a source of conflict between states, chiefdoms, families and individuals. Its centrality to economic development and social welfare is unquestionable as it has been used from time immemorial to promote economic growth and human progress. While land is a birthright of the indigenous people, it has a communal dimension whereby all members of the community are expected to share its resources, under some form of traditional authority who is not only a uniting force but also a steward with divine authority. Rituals related to rain-making, thanksgiving and prayer have historically been tied to the land in Africa and it is also valued as a resource of livelihood because it produces food and water, which give life to all living things (Mufeme, 1997). 
But in spite of the indispensable nature of land as demonstrated above, the Bakweri land surrender scheme was far from achieving the purpose for which it was intended because a catalogue of problems emerged including social agitation, appearance of land grabbing elite, dispossession of indigenous persons, creation of non-existent villages, and land sale mafia. These complications emanated from the fact that CDC made this land cession time-sensitive by putting considerable pressure on the villages to pay the amount requested, or else they would lose the opportunity to obtain the said lands (Ngah, 2014). In order to raise the requisite sum, most of the village leaders resorted to selling parcels of the lands, in advance, to those who would give them the money. This completely negated the raison d'etre for land surrender by CDC to the ethnic and indigenous people most of whom remained landless (Mbua, 2011; Chia, 2014). This situation led to the emergence of a group of elite who petitioned the government and called for judicial inquiries into the dubious land deals. In many press organs and live radio programs, they condemned and exposed them to the world.

As far as the Bakweri land problem is concerned and notwithstanding its benevolence, the government of Cameroon has been painted as persecutor of the Bakweri people, blamed for conniving with the colonial master to seize indigenous land, and mocked as an epitome of bad governance. In actual fact, this has been the work of a very vocal part of the populace bent on "giving the dog a bad name in order to hang it". When the BLCC dragged the government to the Banjul Court in 2002 like an international criminal on five counts, ${ }^{28} \mathrm{Dr}$ Joseph Dion Ngute, ${ }^{29}$ who held brief for the government, argued that the case should be thrown out because BLCC, having been banned in 2002, had no right to speak for the Bakweri people; the case was imprecise and unclear; it was insulting because it had cast suspicions and aspersions on the Cameroonian judicial system; the UN sub commission had already settled it; and that BLCC had not exhausted local remedies (Dibussi, 2006). ${ }^{30}$

However, government continued to work for the general interest of the nation by implementing the provisions of the 1974 land law that was drawn up by the peoples' representative in the National Assembly, including those from Bakweri land. The spirit of this law was to nationalize land in order to forge national integration by harmonizing the numerous tenure systems across the country, break down social barriers and check customs that denied land rights to vulnerable persons like women. Besides, it

28 The five counts were that: CDC land is Bakweri private property; the rightful owners are not fully involved in privatization negotiations; ground rents have not been paid; the Bakweri lack shares in the privatized companies; and BLCC is not represented in CDC policy and management boards.

29 Dr. Joseph Dion Ngute who was then Cameroon's Minister Delegate in charge of Relations with the Commonwealth, was appointed Prime Minister of Cameroon on January 4, 2019.

30 The BLCC and government of Cameroon made oral submissions on November 14, 2003 regarding the admissibility of BLCC vs. State of Cameroon before the African Court in Banjul, Gambia. 
protects every body's interest and not that of a particular group. This explains why its Article 1(2) states that the state shall be the guardian of all land. It may in this capacity intervene to ensure rational use of land or in the imperative interest of defense or the economic policies of the nation. But the Bakweri, having willfully refused to recognize this legal provision as well as the primordial role of the central administration, continued to agitate as if they were a state within a state. This is in spite of the fact that the CDC, which occupies the said lands employs Cameroonians from all nooks and crannies of the nation (Lysinge, personal communication, 2019).

The government has always hearkened to the cries of the Bakweri indigenes by progressively surrendering portions of the lands to village communities when need arises. Since 2003, more than 7,594 hectares have been ceded to the Bakweri and never has any parcel of land been relinquished to non-indigenous persons. Rather, it is the Bakweri themselves, who, after receiving parcels of land, dispose of them for cash to whoever can pay. If there has been much noise about the land problem, it is because there are some of the so-called sons and daughters of the soil with xenophobic tendencies who want to exclude some nationals who are not their kith and kin from enjoying nature's bounties concentrated on Bakweri territory. Besides, some of them, with royal blood deliberately engage in land deals in order to augment their income so as to be like traditional rulers in other parts of the country having palaces endowed with insignias of office, cars and royal paraphernalia (Lysinge, personal communication, 2019).

When noise about the Bakweri land saga reached its peace in 2014, government authorities swung into action again by temporarily deferring the land surrender scheme and suspending a weekly radio programme called "Press Club" run by Cameroon Radio Television (CRTV) Buea in which panelists sarcastically commented on the land palaver. That same year, the Minister of State Property, Surveys and Land Tenure, dismissed Paul Kamchang and Florence Eya Bate from their positions as South West Regional Delegate and Land Registrar respectively while the National Anti-Corruption Commission (CONAC) set up an inter-ministerial commission to investigate alleged corruption charges involving state functionaries (Ambe, 2014; Abah, 2018).

\section{Conclusion}

The interpretation of the 1974 law establishing rules governing land tenure was the chief source of conflict between the BLCC and Cameroon government because both parties have divergent views as to whether Bakweri land is national land or not. This law states inter alia that "national lands shall be divided into two categories namely (1) lands occupied with houses, farms, plantations and grazing lands manifesting human presence and development; (2) lands free of any effective occupation". According to the BLCC, the lands referred to should be those not clearly demarcated or registered anywhere officially. The lands to which they claim hegemony "were entered in the 
Grundbuch ${ }^{31}$ and so do not fall in the category of national lands over which the state has powers of intervention" (Endeley, personal communication, 2007). ${ }^{32}$

However, even as Cameroon law fails to guarantee the land rights of an indigenous minority, there would have been no conflict if the CDC respected the payment of ground rents to the Bakweri and if the government showed any signs of respecting the 60-year land lease agreed upon in 1947. All attempts made by the BLCC to have their lands reinstated have borne little or no fruits because tea plantations have been privatized without the consent of the "legitimate owners" while, safe for recent disturbances by Anglophone separatist fighters from August 2018 to January 2019, CDC's activities on all its plantations went on unperturbed. Meanwhile each time Bakweri indigenes want a piece of CDC land to be relocated to them, they are expected to follow a standard procedure involving CDC board of directors whose decision is subject to the approval of the SDO who is chairman of the land consultative board. This is eloquent testimony that the state is intervening to ensure balanced use of land since it considers CDC landed property to be part of national land. Therefore, Bakweri land rights could only be restored if the country's 1974 landmark land law were revised or if BLCC's interpretation of it was accepted.

Since this did not happen, a small, determined and politically astute minority people under the auspices of the BLCC made clever use of non-violent methods of protest, petitions and demonstrations to draw the attention of a third party, the Banjul Court, in order to vindicate their group rights to land they have traditionally owned, occupied or used since time immemorial. The amicable settlement proposed by the court was instead replaced by a dubious land surrender scheme initiated by state officials that was later halted in 2014 as a result of malpractices. As of March 22, 2019, the findings of the commission of inquiry set up five years earlier by the National Anti-Corruption were still awaited.

In any case, many focus group meetings held with some village members, notables, elite and chiefs, pointed to a general agreement on the way forward for a credible and realistic management plan for the lands. The first is to set up a Fako Strategic Land Management Committee (FSLMC) that will coordinate all activities related to CDC lands, adopt generally accepted principles whereby these lands will be held in trust by the chiefs or designated committees to ensure the proper management of surrendered lands in the interest of the village communities and for posterity. These custodians should sign

31 The Grundbuch is the official German land register and according to Article 13 (2e) of the 1974 land tenure law, lands registered in it are declared private property.

32 Chief E.M.L. Endeley was the paramount ruler of the Bakweri of Buea and retired Chief Judge. He made this statement in a radio he granted to the Cameroon Radion Television (CRTV) in Buea on September 16, 2006. He died in 2015. 
commitment or engagement agreements with the FSLMC embodying the principles of no-sale. In addition, a land trust fund should be created to provide financial resources to villages required to establish 25 to 50 -year development plans comprising viable, short, medium and long-term projects with special focus on youth training and employment.

\section{References}

1. Abah, I. (2018, May 11). Villagers tell Fako land-grabbing administrators to hands-off ancestral heritage. Journal Du Cameroun. Retrieved from https://www.journalducam eroun.com/en/villagers-tell-fako-land-grabbing-administrators-hands-off-ancestralheritage/.

2. ACHPR. (2002, October 4). Communication 26012002: Bakweri Lands Claim Committee vs Cameroon. Banjul, Gambia. Retrieved from http://www.achpr.org/files/ sessions/36th/comunications/260.02/achpr36_260_02_eng.pdf.

3. ACHPR. (2006, February 3). Letter to BLCC Counsel Ref. ACHPRILPROT/COMM 260/ CAMINGL. Banjul, Gambia.

4. Ambe, C. (2014, September 11). Fako Land Scandal: Defunct Villages re-emerging to benefit from land surrender. The Recorder Newsline. Retrieved from https://recorder line.blogspot.com/2014/09/fako-land-scandal-defunct-villages-re.html.

5. Ambe, J. N. (1999). CDC and the Bakweri Land Question. In D. Tande (Ed.), The Bakweri Land Problem and the Privatization of the Cameroon Development Corporation: The Internet Debates (August-December 1999) (pp. 61-66). Buea: BLCC Digital Archive.

6. Bakweri Lands Claim Committee (BLCC). (1948). 1948 Petition of the Bakweri Land Committee of the Cameroons under British Mandate. Journal of the Royal African Society, 18(4), 307.

7. Bakweri People. (1999). Memorandum of the Bakweri People on the Presidential Decree to Privatize or Sell the Cameroon Development Corporation. In D. Tande (Ed.), The Bakweri Land Problem and the Privatization of the Cameroon Development Corporation: The Internet Debates (August-December 1999) (p. 69). Buea: BLCC Digital Archive.

8. Bederman, H. S., \& Delancey, M. (1980). The Cameroon Development Corporation, 1947-1977: Cameroonisation and Growth. In K. K. Ndiva (Ed.), An African Experiment in Nation Building: The Bilingual Cameroon Republic since Reunification (pp. 251-278). Boulder: Westview Press.

9. Cheabi, E. (1997). The Making of Modern Cameroon: A History of Substrate Nationalism and Disparate Union, 1914-1961, Vol. I. Boston: University Press of America.

10. Chia, C. N. (2014, October 18). Special Feature From Cameroon: Serial Land-Grabbers and Royal Accomplices: In-Depth Report. Modern Ghana. Retrieved from https://www. modernghana.com/news/575358/special-feature-from-cameroon-serial-land-grab bers-and-roya.html.

11. Dibussi, T. (2006, March 6). A Brief History of the Bakweri Land Problem. Buea: BLCC Communications Department. 
12. Eno, C O., \& Fombe, L. F. (2016). Development Implications of Ceded Lands by the Cameroon Development Corporation Fako Division - South West Region of Cameroon from 1960 to 2010. Advances in Social Sciences Research Journal,3(11), 154-164.

13. Fako Chiefs. (1999). Memorandum Dated $3^{\text {rd }}$ March 1999 to HE Paul Biya Concerning the Privatization of the Cameroon Development Corporation (CDC). BLCC Archives. Retrieved from https://www.blccarchives.org/2006/07/blcc_memorandum.html.

14. Kale, P. M. (1967). Political Evolution in the Cameroons. Buea: Government Printing Press.

15. Kofele-Kale, N. (2007). Asserting Permanent Sovereignty over Ancestral Lands: The Bakweri Land Litigation against Cameroon. Annual Survey of International and Comparative Law, 13(1), 102-156.

16. Mbua, L. E. (2011, January 30). Land Surrender by CDC to the Indigenes of Fako: The Obligation and Challenges of Preserving Fako Ancestral Lands for Fako Indigenes and Posterity. Up Station Mountain Club. Retrieved from https://www.postnewsline. com/2011/01/press-release-cameroon-the-bakweri-lands-and-the-abuse-of-a-peo ple.html.

17. Mbuagbo, O. T., \& Lambi C. M. (2003). Some Aspects of Land Conflicts in the Mount Cameroon Region. Journal of Applied Social Sciences, 3(I), 67-80.

18. Monono, H. N. (2006). Arrogance, Ignorance of CDC/Bakweri Lands Imbroglio. Up Station Mountain Club. Retrieved from http://www.postnewsline.com/2006/11/arroga nce_ignor.html.

19. Mufeme, E. (n.d.). Land and Spirituality in Africa. Echoes. Retrieved from http://www. wcc-coe.org/wcc/what/jpc/echoes-16-05.html.

20. Nana, W. W. (2014, August 20). Fako Land Grabbing Saga: Chiefs Renounce Protest, Denounce Foxy Colleague. The Post Newspaper, 1054, pp. 15-16.

21. National Archives Buea (NAB). (1946). Petition on Claim of the Bakweri Lands under the Crown, Custodian and Missionary Bodies situated in the Victoria Division of the Cameroons under British Mandate, File Qf/a 1946/2. Buea: National Archives Buea

22. Neba, S. F. (2010). The Contribution of Higher Education to Regional Socio-Economic Development: The University of Buea as a Grwoth Pole. Unpublished Dissertation paper presented at the University of Cape Town, South Africa.

23. Ngah, C.. (2014, July 23). Fako Land-grabbing Administrators Panic as Government, CONAC set to open investigation. The Guardian Post. Retrieved from http://guardian postonline.blogspot.com/2014/07/fako-land-grabbing-administrators-panic.html.

24. Ngange, K. L. (2014). Fako Division Land Crisis Part One: What CRTV Buea's Press Club Did not Say (Part 1). Fako News Centre. Retrieved from https://www.fakonewscentre. com/fakolandcrisis1.htm.

25. Ngoh, V. J. (1996). History of Cameroon since 1800. Limbe: Presbook.

26. Ngongi, N. I. (2013, June 6). Land Surrender by CDC to the indigenes of Fako: The Obligation and Challenges of Preserving Fako Ancestral Lands for Fako Indigenes and 
Posterity. Urgent Memorandum to Mr. Zang III, The Senior Divisional Officer for Fako Limbe, Fako Division South West Region Cameroon.

27. Ngongi, N. I. (2014, April 22). Cameroon: The True Nature of the Fako (Bakweri) Land Crisis and A Callforan Immediate, Lasting Solution. The Recorder Newsline, p. 10.

28. Ngwoh, V. K. (2016). The Dynamics of Farmer-Herder Conflicts across the Bamenda Grassfields, 1947-2006. Saarbruchen: Lambert Academic Publishing.

29. Tande, D. (1999). The Bakweri Land Problem and the Privatization of the Cameroon Development Corporation: The Internet Debates (August-December 1999). Buea: BLCC Digital Archive. 